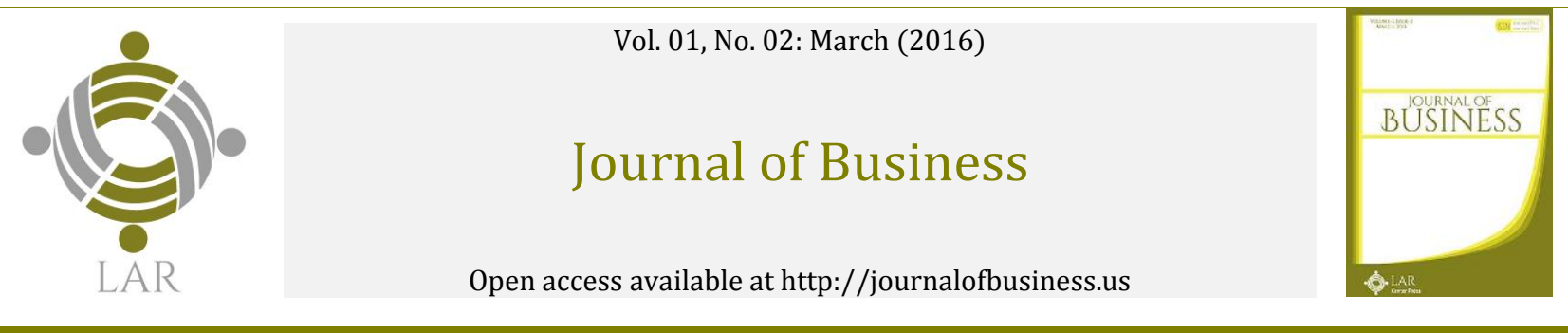

\title{
Default Risk Assessment of Tunisian SMEs: Multiple Criteria Decision Making Approaches
}

\author{
Salah Ben Hamad a*, Nesrine Turki ${ }^{b}$ \\ a Université de Sfax, Faculté des Sciences Économiques et de Gestion de Sfax, Tunisie. \\ b Université de Monastir, Faculté des Sciences Économiques et de Gestion de Mahdia, Tunisie. \\ ${ }^{*}$ Corresponding author's email address: benhamad_salah@yahoo.fr.
}

A R T I C L E I N F O

Received: 03-01-2016

Accepted: 21-02-2016

Available online: 30-03-2016

Keywords:

default risk,

ELECTRE III,

ELECTRE TRI,

Tunisian SMEs,

JEL Classification:

\section{A B S T R A C T}

The default risk is a reality as well for the companies as for the economy of a country. This paper has highlighted the fact that in spite of the many incentives to promote Tunisian SMEs, creation of these companies remains below expectations. Thus, a study assessing the risk of failure is imperative. A multicriteria methodology of decision-making in a sample of 41 small and medium-sized enterprises used financing by the Tunisian Solidarity Bank (BTS) as one of the financial support structures relative to investment credits. The results showed that the application of a policy of caution (pessimistic procedure) in the granting of loans by the BTS is the main obstacle to the creation, development and sustainability of the Tunisian SMEs.

(C) 2016 The Authors. This is an open access article under the terms of the Creative Commons Attribution License 4.0, which allows use, distribution and reproduction in any medium, provided the original work is properly cited.

DOI: http://dx.doi.org/10.18533/job.v1i2.16

\subsection{Introduction}

SMEs have become the engine of economic growth, the best way for innovation and the conquest of the major markets increasingly open on the outside, the fight against unemployment, poverty and social inequality (Halleberg, 2000; Audretsh, 2002; Gallina, 2002).

SMEs have a significant impact on the technical progress of a country. They tend to have more flexibility and dynamism which constitute its main advantages (Edwards and al., 2005) and a culture more conducive to creativity and thus to the innovation (Belz and Gauthier, 2000).

Varun Dhawar (2014) is written, based on the agency theory, a vast literature examines the relationship between capital structure and performance since the seminal work of Modigliani and Miller (1958). While most of these studies explore the relationship in developed countries, little is known about these implications empirically in emerging economies such as India. This study examines the impact of the capital structure choices on the performance of listed companies in India as one of the emerging countries It's in this context that the Tunisian public authorities took several and additional varied measures to support the creation, the development and the sustainability of the Tunisian SMEs through three main structures of support namely: logistics support structures, structures of financial support (incentives related to capital, incentives related to investment credits, incentives relating to guarantees and office Upgrade (BMN)) and the international support structures. 
"Why the majority of Tunisian SMEs suffer from financial difficulties and failure despite the diversity of measures implemented to support the creation, development and sustainability thereof?" Obtaining loans appears to be the major constraint on the growth and sustainability of Tunisian SMEs. Indeed, creditors working with depositors' savings accept to grant credit when ensuring that borrowers are creditworthy and will be able to honor their debt. Thus, the purpose of this research is to assess the default risk of a sample of 41 Tunisian SMEs funded by the Tunisian Solidarity Bank (BTS) as one of Financial Support structures on investment loans.

Many analysts seem to agree that the Tunisian SMEs show several weaknesses in their internal structure and their environment. Thus, we were able to identify three main problems companies namely: the problems of asymmetric information, agency problems and governance.

Indeed, the financial literature agrees on the fact that the financing of SMEs is mainly characterized by limited access to different sources of funds because of their opacity access (Ang, 1991; 1992). Problems of information asymmetry have been studied, among others, by Leland and Pyle (1977), Myers and Majluf (1984), Berger and Udell (1998) and Nahmias (2005), as the problem which can lead to a rationing of the bank credit that would be likely to penalize investment and growth.

Berger, Rosen and Udell (2007) and Cole, Goldberg and White (2004), propose alternative specific formulas limiting problems associated with asymmetric information: use of scoring, leasing, mortgages, etc. In addition, the agency theory or the theory of terms is commonly used to describe the relationship between shareholders and managers as the control mechanism of the first on the second. Thus, proponents of this theory believe that the causes of its failure to seek rather the failure of a system of contractual relations. (Jensen and Meckling 1976; Smith and Warner 1979).

Charreaux, (1997), defined the governance as all the mechanisms which have for effect to bind the powers and to influence the decisions of the managers, in other words, which govern their conduct and define their discretionary space. Indeed, in front of the report of behavior obviously deviants on behalf of certain managers having led to the despoilment of numerous shareholders, the explanation of the phenomena of governance in terms of conflicts of interests such as proposed by the positive theory of the agency (TPA) seemed to have imposed (Daily and al., 2003; Jensen, 1986; Jensen and Meckling 1976). So, from the point of view of the efficiency, the central issue of governance mechanisms consists of their impact on the value creation.

In this specific context two major causes of failure have been identified: internal causes or micro-economic and macro-economic or external causes. Indeed, internal failure factors can be grouped into three categories related to deficiencies in the management, the structure of the company and, in a minor way, the economic environment (Crufix and Derni, 1993). Several researchers have established a link between the phenomenon of bankruptcies and various macroeconomic factors mainly: the supervision of credit (Condition credit and money market) and the flow of business creation and, to a lesser extent, growth economic activity, the performance of the stock market and inflation.

The banking financing appears as the heaviest constraint on these companies. The problem of access or obtaining bank credit faced by Tunisian SMEs has a significant negative impact not only on the growth and survival of these companies, but also on the entrepreneurial phenomenon and the private sector in general. It constitutes a real threat in the success of the Tunisian economy opening. (Adair and Fhima, 2009).

Ye (George) Jia (2009) shows through the model life cycle hardness regulations in bankruptcy prevent households to invest. Lee, Yamakawa and Peng (2007), Armour and Cumming (2005) found that entrepreneurs become averse to risk in countries with tough regulations bankruptcy. Finally, Armour and Cumming (2005) show through a study of 15 countries over 16 years that more the regulations of bankruptcy are flexible more the rate of employment increases.

Furthermore, the rash of the young companies may stress the number of the failures. These young companies know, indeed, a high rate of mortality. Altman (1983), Koenig (1985) and Sharabany (2004) argue that companies go bankrupt when they are small. Koenig (1985): "50\% of bankruptcies are due to the company having age less than five years". Lawless and Warren (2005) argue that in USA more than $20 \%$ of the bankruptcies are attributed to small businesses.

Finally, the evaluation of companies default risk will be essential, because it consists in supplying alert signals and important information for the managers, the investors, the creditors and the auditors. This research is structured as follows: The second section presents the methodology of this study. The results of the multicriteria decision-making analysis are illustrated in the third section. Finally, we conclude with the main points drawn from the empirical study. 


\subsection{Methodology}

We chose the multicriteria decision-making approach to estimate the default risk of a sample of 41 Tunisian SMEs funded by the Tunisian Solidarity Bank (BTS) of Mahdia, as one of the financial support structures on investment credits from accounting data recorded for 2013.

This is in line with prior research which suggests that size of the firm may have an manipulate on its performance owing to differences in operating environment, access to the markets, diversification of business and information asymmetry (Ebaid, 2009; Sadeghian et al., 2012).

\subsection{Multicriteria decision-making approches}

Vincke (1989): "Multicriteria decision-making aims, as its name suggests, providing a decision maker with tools to make progress in solving the problem or making several points of view, often contradictory, must be taken into account." Roy (1985) distinguishes four problematic references decision process whose characteristics are described as follows:

\begin{tabular}{|c|c|c|c|}
\hline \multicolumn{4}{|c|}{ Table 1: Issues reference Roy } \\
\hline \multicolumn{2}{|l|}{ Problematic } & Target & Result \\
\hline \multicolumn{2}{|l|}{$P \alpha$} & $\begin{array}{l}\text { Illuminate the decision by selecting a subset as small as possible for a } \\
\text { final choice of a single action. }\end{array}$ & $\begin{array}{l}\text { A choice or selection } \\
\text { procedure. }\end{array}$ \\
\hline \multirow{2}{*}{\multicolumn{2}{|c|}{$\begin{array}{l}P_{\beta} \\
\text { (ELECTRE } \\
\text { Method) } \\
P \gamma \\
\text { (ELECTRE } \\
\text { Method) }\end{array}$}} & $\begin{array}{l}\text { Illuminate the decision sort resulting from use of each action category; } \\
\text { categories are defined a priori based on predetermined standards }\end{array}$ & $\begin{array}{l}\text { Sorting or assignment } \\
\text { procedure }\end{array}$ \\
\hline & & $\begin{array}{l}\text { Illuminate the decision by a storage obtained by aggregating all or part } \\
\text { ("most satisfactory") actions into equivalence classes, these classes are } \\
\text { ordered, complete or in part, in accordance with the preferences }\end{array}$ & $\begin{array}{l}\text { A storage or } \\
\text { classification procedure }\end{array}$ \\
\hline \multirow{2}{*}{\multicolumn{2}{|c|}{$P \delta$}} & $\begin{array}{l}\text { Illuminate the decision by a description of the actions and their } \\
\text { consequences }\end{array}$ & $\begin{array}{l}\text { A description or } \\
\text { cognitive procedure }\end{array}$ \\
\hline & & Source: Roy (1985) & \\
\hline
\end{tabular}

We apply two methods appropriate to our problem: the ELECTRE III method for a storage or filing actions in 3 business categories (healthy firms, risky and failing) then apply the ELECTER TRI method that can illuminate the decision sort resulting from use of each action to a predefined based on two selected profiles categories: optimistic and pessimistic profile.

\subsection{Multicriteria decision-making steps}

Presentation of the potential actions

$A=\left\{a_{1}, a_{2}, \ldots, a_{m}, \ldots\right\}$ the set of potential actions that represent our sample of firms (healthy, risky and failing).

The construction of the criteria (gj)

To measure the financial health of companies and among the different models that exist in the literature, a synthesis of four chief studies relative to the bankruptcy (Collongues (1977), Conan and Holder (1979), Altman et al. (1994) can constitute the basic railing of any preventive approach, given the performance of selected financial ratios whose predictive power is the highest.

Table 2: Synthesis of four chief studies relative to the bankruptcy

\begin{tabular}{|c|c|c|c|}
\hline $\begin{array}{c}\text { COLLONGUES } \\
\text { (1977) }\end{array}$ & $\begin{array}{c}\text { CONAN \& HOLDER } \\
\text { (1979) }\end{array}$ & $\begin{array}{l}\text { ALTMAN \& al. } \\
\text { (1994) }\end{array}$ & $\begin{array}{l}\text { CREDIT-MEN } \\
\text { (1995) }\end{array}$ \\
\hline Financial expenses & capitalization & \multirow{2}{*}{$\begin{array}{c}\begin{array}{c}\text { Turnover (excluding } \\
\text { taxes) }\end{array} \\
\text { total Assets }\end{array}$} & Practicable + Available \\
\hline $\begin{array}{l}\text { Turnover (excluding } \\
\text { taxes) }\end{array}$ & total liabilities & & short term debts \\
\hline Operating profits & Gross operating profit & Reserves & Own capital \\
\hline $\begin{array}{c}\text { Turnover(excluding } \\
\text { taxes) }\end{array}$ & Total debts & total Assets & Total debts \\
\hline Profitability \& & Balance of financial & Capital turnover \& & Balance of financial \\
\hline Productivity & $\begin{array}{l}\text { structure and } \\
\text { economic profitability }\end{array}$ & Economic Profitability & structure \\
\hline
\end{tabular}


According to Conan and Holder (1979), Altman et al. (1994): "Most of the studies and statistics on the causes of failures in all cases consistent on two points: reviewing all the behavior of the firm and, in particular, that of its leaders." That's why, it is imperative to introduce a strategic variable (Experience of the management team). This criterion will be estimated on an ordinal scale [1-5]:

\begin{tabular}{lrl}
\hline & Table 3: ordinal scale [1-5] \\
\hline Ordinal scale & Coding & Meaning of levels \\
\hline Experience $\leq 1$ year & 1 & Low experience of the management team \\
1< Experience $<3$ years & 2 & Average experience of the management team \\
$3<$ Experience $<5$ years & 3 & pretty good experience of the management team \\
$5<$ Experience $<10$ years & 4 & Good level of experience of the management team \\
Experience $\geq 10$ years & 5 & Excellent level of experience of the management team \\
\hline Source: made by us & & \\
\hline
\end{tabular}

\section{Determination of criteria weights $\left(\Sigma \mathbf{w}_{\mathrm{i}}=1\right)$}

Roy (1988): The criteria are weighted according to their importance:

- A criterion is less important than the other (0.5)

- Importance equal on both criteria (1)

- A criterion is slightly larger than the other (2)

- A criterion is more important than the other (3)

- A criterion is much more important than the other (4)

\begin{tabular}{lrrrrrrrrrrr}
\hline \multicolumn{10}{c}{ Table 4: Matrix of criteria weights } \\
\hline & g1 & g2 & g3 & g4 & g5 & g6 & g7 & g8 & g9 & Total & normalized weight \\
\hline g1 & & 2 & 3 & 4 & 3 & 4 & 1 & 0.5 & 1 & 18.5 & 0.12 \\
g2 & 2 & & 4 & 3 & 3 & 2 & 1 & 1 & 1 & 17 & 0.11 \\
g3 & 0.5 & 2 & & 0.5 & 2 & 2 & 2 & 0.5 & 1 & 10.5 & 0.07 \\
g4 & 2 & 2 & 3 & & 2 & 2 & 2 & 0.5 & 1 & 14.5 & 0.09 \\
g5 & 2 & 1 & 4 & 3 & & 2 & 0.5 & 0.5 & 1 & 14 & 0.09 \\
g6 & 3 & 2 & 3 & 3 & 4 & & 3 & 2 & 1 & 21 & 0.14 \\
g7 & 4 & 3 & 3 & 2 & 4 & 3 & & 3 & 1 & 23 & 0.15 \\
g8 & 4 & 4 & 4 & 4 & 3 & 3 & 4 & & 1 & 27 & 0.18 \\
g9 & 1 & 1 & 1 & 1 & 1 & 1 & 1 & 1 & & 8 & 1.00 \\
Total & 18.5 & 17 & 25 & 20.5 & 22 & 19 & 14.5 & 9 & 8 & 153.5 & \\
\hline Source: & made by us & & & & & & & & & \\
\hline
\end{tabular}

The discrimination thresholds (Roy 1985)

The preference threshold (p): where the performance of an action is preferred to the performance of an action $b$. The indifference threshold (q): where the performance of a share is equal to the performance of an action $b$.

The threshold of Veto (v): the threshold is defined as the limit above which the two actions are considered not comparable even if shares are mostly better than the other and on the other criteria.

\subsection{Results of the multicriteria decision-making analysis}

\subsection{Application of the ELECTRE III method for the classification of potential actions identified}

The method of analysis multicriterion ELECTRE III method was proposed by Roy (1978) is based on the construction of an alternative classification, through a partial aggregation approach to performance. Its objective is to compare and rank potential actions whose performance is known on a set of criteria, it is to test the hypothesis upgrade " $a_{i}$ outperformed $a_{k}$ " through validation tests of credibility that it can grant. To do this, actions valuations are compared pair wise for each criterion (Roy, 1978).

The particularity of this method is to involve pseudo-criteria in the classification of potential actions from the best to the worse. Bouyssou and Roy (1987), define a pseudo-criterion as a function g whose discriminative power is characterized by thresholds ( $\mathrm{q}$ indifference threshold and p preference threshold), allowing to distinguish a low preference and a strict preference.

The man of study admits, for two actions $\mathrm{a}$ and $\mathrm{b}$ :

$g\left(a_{k}\right) \geq g\left(a_{i}\right) \Longrightarrow\left\{\begin{array}{ll|}g\left(a_{k}\right) I g\left(a_{i}\right) & \text { if } g\left(a_{k}\right)-g\left(a_{i}\right)<q\left[g\left(a_{i}\right)\right] \\ g\left(a_{k}\right) Q g\left(a_{i}\right) & \text { if } q\left[g\left(a_{i}\right)\right]<g\left(a_{k}\right)-g\left(a_{i}\right)<p\left[g\left(a_{i}\right)\right] \\ g\left(a_{k}\right) P g\left(a_{i}\right) & \text { if } \mathbf{p}\left[g\left(a_{i}\right)\right]<g\left(a_{k}\right)-g\left(a_{i}\right)\end{array}\right.$


This analysis can be carried out according to the following four phases:

-Phase 1: Establish the performance table

-Phase 2: Calculate the concordance indices and / or discordance

-Phase 3: Establish indices degree of credibility

-Phase 4: Harnessing the relationship fuzzy upgrade through a downward distillation and

distillation bottom synthesized by the presentation of final results

\section{The performance table}

We recall the performance table is a double entry table where each row corresponds to an action and each column to a criterion, the evaluation of each criterion is denoted $\mathrm{g}_{j}\left(\mathrm{a}_{\mathrm{i}}\right.$ ), (action performance was according to the criterion $\mathrm{g}_{\mathrm{j}}$ ).

\begin{tabular}{|c|c|c|c|c|c|c|c|c|c|}
\hline \multirow{2}{*}{$\begin{array}{l}\text { Actions } \\
\text { (companies) }\end{array}$} & \multicolumn{7}{|c|}{$\begin{array}{c}\text { Table 5: Performance of actions considered } \\
\text { Evaluation Criteria }\end{array}$} & \multirow[b]{2}{*}{ g8 } & \multirow[b]{2}{*}{$\mathrm{gc}$} \\
\hline & g1 & g2 & g3 & g4 & g5 & g6 & g7 & & \\
\hline A0001 & 11.59 & 1.5 & 22.49 & 1.82 & -1.01 & 1.04 & 0.57 & 11.6 & 5 \\
\hline A0002 & 2.54 & 0.07 & 0.32 & 0.34 & 30.01 & -1.9 & 0.07 & 0.38 & 1 \\
\hline A0003 & 28.65 & 15.55 & 31.26 & 1.85 & -2.09 & 14.77 & 1.5 & 24.79 & 5 \\
\hline A0004 & 23.9 & 14.5 & 28.51 & 1.83 & -1.5 & 13.34 & 1.43 & 15.02 & 4 \\
\hline A0005 & 30.01 & 15.44 & 32.01 & 2.23 & -3.67 & 15.02 & 1.01 & 26.03 & 5 \\
\hline A0006 & 33.07 & 17.01 & 33.52 & 3.55 & -4.33 & 15.21 & 1.01 & 26.03 & 5 \\
\hline A0007 & 29.08 & 16.02 & 31.5 & 1.9 & -2.59 & 14.32 & 1.59 & 25.85 & 5 \\
\hline A0008 & 29.22 & 16.23 & 31.69 & 2.01 & -3.02 & 14.56 & 1.61 & 25.67 & 4 \\
\hline A0009 & 31.09 & 16.53 & 32.52 & 2.54 & -3.84 & 14.99 & 1.63 & 27.03 & 4 \\
\hline A0010 & 25.76 & 15.18 & 29.77 & 1.86 & -1.63 & 13.56 & 1.43 & 22.96 & 4 \\
\hline A0011 & 25.04 & 15.06 & 29.51 & 1.84 & -1.6 & 13.38 & 1.4 & 22.78 & 5 \\
\hline A0012 & 27.34 & 15.54 & 30.93 & 1.85 & -1.99 & 14.23 & 1.5 & 24.44 & 4 \\
\hline A0013 & 27.07 & 14.51 & 30.53 & 1.86 & -1.87 & 14.12 & 1.51 & 24.23 & 4 \\
\hline A0014 & 24.87 & 14.33 & 28.02 & 1.77 & -1.43 & 13.78 & 1.33 & 21.99 & 4 \\
\hline A0015 & 24.45 & 14.75 & 29.15 & 1.9 & -1.53 & 13.44 & 1.39 & 20.77 & 4 \\
\hline A0016 & 21.44 & 14.01 & 27.49 & 1.69 & -1.39 & 21.39 & 1.23 & 21.67 & 3 \\
\hline A0017 & 19.45 & 13.51 & 26.68 & 0.99 & -1.23 & 12.01 & 0.79 & 19.62 & 2 \\
\hline A0018 & 20.04 & 13.56 & 27.27 & 1.53 & -1.3 & 12.13 & 1.02 & 20.33 & 4 \\
\hline A0019 & 28.66 & 15.59 & 31.01 & 1.86 & 2.24 & 14.79 & 1.58 & 24.82 & 5 \\
\hline $\mathrm{A} 0020$ & 19.77 & 13.53 & 26.89 & 0.88 & -1.15 & 12.09 & 0.81 & 17.99 & 3 \\
\hline A0021 & 34.01 & 16.26 & 34.22 & 4.67 & -4.66 & 15.56 & 1.64 & 27.85 & 5 \\
\hline A0022 & 15.69 & 2.21 & 24.71 & 0.87 & -1.1 & 1.92 & 0.69 & 15.88 & 4 \\
\hline A0023 & 16.9 & 27.9 & 25.19 & 0.82 & -1.21 & 11.99 & 0.73 & 17.99 & 4 \\
\hline A0024 & 12.67 & 1.75 & 23.44 & 0.61 & 2.01 & 1.59 & 0.64 & 10.52 & 3 \\
\hline A0025 & 12.89 & 1.56 & 23.95 & 0.53 & 2.44 & 1.5 & 0.55 & 11.34 & 3 \\
\hline A0026 & 10.89 & 0.1 & 22.33 & 0.22 & 13.75 & -3.22 & 0.42 & 10.05 & 2 \\
\hline A0027 & 11.68 & 1.01 & 22.8 & 0.39 & -1.65 & 0.66 & 0.11 & 11.89 & 2 \\
\hline A0028 & 10.99 & 0.15 & 22.86 & 0.39 & 13.96 & -3.67 & 0.66 & 10.9 & 2 \\
\hline A0029 & 15.67 & 2.26 & 24.45 & 0.57 & -1.03 & 1.64 & 0.23 & 15.63 & 3 \\
\hline $\mathrm{A} 0030$ & 15.03 & 2.5 & 24.03 & 0.81 & -1.12 & 1.89 & 0.59 & 15.69 & 3 \\
\hline A0031 & 16.44 & 2.88 & 22.98 & 0.92 & -1.19 & 11.98 & 0.68 & 17.44 & 3 \\
\hline A0032 & 4.55 & 0.093 & 2.56 & 0.38 & 22.67 & -3.55 & 0.082 & 0.77 & 1 \\
\hline A0033 & 6.99 & 0.18 & 3.88 & 0.49 & 19.44 & -3.99 & 0.084 & 0.78 & 1 \\
\hline A0034 & 9.88 & 0.157 & 20.04 & 0.69 & 13.67 & -4.24 & 0.091 & 10.88 & 1 \\
\hline A0035 & 6.94 & 0.12 & 3.77 & 0.56 & 17.88 & -4.13 & 0.086 & 0.84 & 1 \\
\hline A0036 & 3.56 & 0.085 & 0.98 & 0.39 & 21.5 & -2.89 & 0.079 & 0.68 & 1 \\
\hline A0037 & 2.02 & 0.066 & 0 & 0.32 & 29.78 & -1.2 & 0.072 & 0.43 & 1 \\
\hline A0038 & 1.86 & 0.053 & 0 & 0.29 & 33.68 & -0.95 & 0.063 & 0.29 & 1 \\
\hline A0039 & 3.01 & 0.081 & 0 & 0.33 & 25.04 & -2.68 & 0.075 & 0.55 & 1 \\
\hline A0040 & 3.77 & 0.087 & 1.56 & 0.48 & 19.33 & -3.73 & 0.08 & 0.71 & 1 \\
\hline A0041 & 4.16 & 0.09 & 0 & 0.43 & 22.12 & -3.29 & 0.081 & 0.68 & 1 \\
\hline qi & 2 & 1 & 0 & 0.5 & 0 & 0 & 0.05 & 1 & 1 \\
\hline pi & 33 & 27.8 & 34.22 & 4.5 & 30 & 19 & 1.6 & 27.7 & 5 \\
\hline vi & 33 & 27.8 & 34.22 & 4.5 & 30 & 19 & 1.6 & 27.7 & 5 \\
\hline wi & 0.12 & 0.11 & 0.07 & 0.09 & 0.09 & 0.14 & 0.15 & 0.18 & 0.05 \\
\hline Meaning & Max & Max & Max & Max & Min & Max & Max & Max & Max \\
\hline
\end{tabular}

(With $\mathrm{q}_{\mathrm{i}}, \mathrm{p}_{\mathrm{i}}$, and $\mathrm{v}_{\mathrm{i}}$ and $\mathrm{w}_{\mathrm{i}}$ are respectively the indifference threshold, the preference threshold, the veto threshold and weight corresponding to the $\mathrm{i}^{\text {th }}$ criteria). 


\section{Concordance indices}

Matrix concordance shows all indices overall concordance of action pairs ( $\left.a_{i}, a_{k}\right)$ when $a_{i}$ outperforms $a_{k}\left(a_{i} S a_{k}\right)$ ) (Roy 1978). This option is only available for projects "ELECTRE III" type. After realizing matrices corresponding to each action (m: matrix of size $n^{*} n$ ) and comprising the corresponding indices $c_{j}\left(a_{i}, a_{k}\right)$, a matrix indices corresponding overall size of $41 * 41$ is then performed.

\section{Indices degree of credibility}

Measurement lends credibility to the hypothesis upgrade ( $a_{i}$ outperforms $a_{k}\left(a_{i} S a_{k}\right)$ ) degrees of credibility $\delta_{i k}$. These indices are calculated by taking into account all the conflicting criteria (for which ak is strictly preferred to $\mathrm{a}_{\mathrm{i}}$ ) and the threshold values of veto (Roy 1978). The values of these degrees for our problem are presented in a matrix degree of overall credibility of size $41 * 41$.

\subsection{Exploitation of fuzzy relationship upgrade and presentation of results}

The first relation is obtained from the top down, by selecting the best action and classifying other actions best to worst, it is called downward distillation (see Appendix). The second is from the bottom up, by first choosing the wrong action, and ranking of the worst to the best action, it is called bottom distillation, ultimately synthesized by a final ranking.

The interpretation of the results of the multicriteria method ELECTRE III can highlight the following points: It is clear that the best action is healthy businesses because they are the best solutions ranked by contribution to other actions, or if they are considered the most successful on all nine criteria.

And thus through the ranks in the final pre order (see Appendix), we can combine healthy companies into a single category (C03: A0021 , A0006, A0009 , A0007 , A0008 , A0019 , A0003 , A0005 , A0012 , A0013 , A0004 , A0010 , A0011 , A0014 , A0015 , A0016 , A0018 , A0023 , A0017 , A0020 , A0031 and A0022) . So the category C03 represents 22 healthy firms $(\mathrm{CO3}=22)$.

The second category is now occupied by the actions or risky companies, which are considered less efficient than the previous category on new evaluation criteria. And thus through the ranks in the final pre order (see Appendix) , can be grouped in a single risky business category (C02: A0001, A0024 , A0029 , A0030 , A0025 , A0027, A0028, A0026 and A0034). So the category C02 represents 09 companies risky $(\mathrm{C} 02=09)$.

The third and final category is present in the most vulnerable companies are those already bankrupt and are still less efficient than the previous two categories (C03 and C02) on new evaluation criteria. And thus through the ranks in the final pre order (see Appendix), we can combine the failing firms in one category (C01: A0035, A0032 , A0033 , A0036 , A0037 , A0039 , A0040 , A0041 , A0002 , A0038). So the category C01 represents 10 companies failed $(\mathrm{C} 01=10)$.

\subsection{Application of ELECTRE TRI method for the upgrade potential actions identified on two different reference profiles (optimistic and pessimistic)}

The ELECTRE TRI method that is specially designed for Multi- segmentation problems , proposes two different allocation procedures, one pessimistic and the other optimistic, which allow the classification of all actions to these categories. ELECTRE TRI, therefore, is to establish a relationship between actions to upgrade and affect the Reference actions.

According to $\mathrm{Yu}$ (1982), the preconditions for establishing the relationship between these two types of actions are:

The evaluation criteria are pseudo- criteria;

The table of actions performance is built;

All reference profiles are defined. In addition, for each reference profile $r$, are given preference thresholds $p_{j}(r)$ and $\mathrm{q}_{\mathrm{j}}$ indifference $(\mathrm{r})$ and $\mathrm{v}_{\mathrm{j}}$ veto $(\mathrm{r})$ whether, for each criteria $\left(\mathrm{g}_{\mathrm{j}}\right)$.

The relative importance of the evaluation criteria is expressed as a weight wi which are already predefined in the ELECTRE III method.

A real value $\lambda$ which varies between 0.5 and 1 and equal default ELECTRE TRI $(\lambda=0.75)$ software; it is called cutting level. 
The ELECTRE TRI method applies only in the case of perfectly ordered category, these categories are defined by reference profiles (a low profile and high profile), which are defined by their performance evaluated on the criteria.

\section{The performance table}

The categories are already predefined by the previous method (ELECTRE III):

Category of firms deemed "more efficient", C03: healthy firms.

Category of firms deemed "less efficient" C02: risky business.

Category of firms deemed "non-performing", C01: failing firms.

The ELECTRE TRI method applies only in the case of perfectly ordered higher category at the lowest categories (healthy companies, risky and failing).

\begin{tabular}{|c|c|c|c|c|c|c|c|c|c|c|}
\hline \multicolumn{11}{|c|}{ Table 6: Performance of actions organized by category } \\
\hline \multirow{2}{*}{$\begin{array}{l}\text { Actions } \\
\text { (Companies) }\end{array}$} & \multirow{2}{*}{ Categories } & \multicolumn{9}{|c|}{ Evaluation Criteria } \\
\hline & & g1 & g2 & g3 & g4 & g5 & g6 & g7 & g8 & g9 \\
\hline A0021 & & 34.01 & 16.26 & 34.22 & 4.67 & -4.66 & 15.56 & 1.64 & 27.85 & 5 \\
\hline A0006 & & 33.07 & 17.01 & 33.52 & 3.55 & -4.33 & 15.21 & 1.01 & 26.03 & 5 \\
\hline A0009 & & 31.09 & 16.53 & 32.52 & 2.54 & -3.84 & 14.99 & 1.63 & 27.03 & 4 \\
\hline A0007 & & 29.08 & 16.02 & 31.5 & 1.9 & -2.59 & 14.32 & 1.59 & 25.85 & 5 \\
\hline A0008 & & 29.22 & 16.23 & 31.69 & 2.01 & -3.02 & 14.56 & 1.61 & 25.67 & 4 \\
\hline A0019 & & 28.66 & 15.59 & 31.01 & 1.86 & 2.24 & 14.79 & 1.58 & 24.82 & 5 \\
\hline A0003 & & 28.65 & 15.55 & 31.26 & 1.85 & -2.09 & 14.77 & 1.5 & 24.79 & 5 \\
\hline A0005 & & 30.01 & 15.44 & 32.01 & 2.23 & -3.67 & 15.02 & 1.01 & 26.03 & 5 \\
\hline A0012 & & 27.34 & 15.54 & 30.93 & 1.85 & -1.99 & 14.23 & 1.5 & 24.44 & 4 \\
\hline A0013 & & 27.07 & 14.51 & 30.53 & 1.86 & -1.87 & 14.12 & 1.51 & 24.23 & 4 \\
\hline A0004 & & 23.9 & 14.5 & 28.51 & 1.83 & -1.5 & 13.34 & 1.43 & 15.02 & 4 \\
\hline A0010 & $\mathrm{CO3}$ & 25.76 & 15.18 & 29.77 & 1.86 & -1.63 & 13.56 & 1.43 & 22.96 & 4 \\
\hline A0011 & & 25.04 & 15.06 & 29.51 & 1.84 & -1.6 & 13.38 & 1.4 & 22.78 & 5 \\
\hline A0014 & & 24.87 & 14.33 & 28.02 & 1.77 & -1.43 & 13.78 & 1.33 & 21.99 & 4 \\
\hline A0015 & & 24.45 & 14.75 & 29.15 & 1.9 & -1.53 & 13.44 & 1.39 & 20.77 & 4 \\
\hline A0016 & & 21.44 & 14.01 & 27.49 & 1.69 & -1.39 & 21.39 & 1.23 & 21.67 & 3 \\
\hline A0018 & & 20.04 & 13.56 & 27.27 & 1.53 & -1.3 & 12.13 & 1.02 & 20.33 & 4 \\
\hline A0023 & & 16.9 & 27.9 & 25.19 & 0.82 & -1.21 & 11.99 & 0.73 & 17.99 & 4 \\
\hline A0017 & & 19.45 & 13.51 & 26.68 & 0.99 & -1.23 & 12.01 & 0.79 & 19.62 & 2 \\
\hline A0020 & & 19.77 & 13.53 & 26.89 & 0.88 & -1.15 & 12.09 & 0.81 & 17.99 & 3 \\
\hline A0031 & & 16.44 & 2.88 & 22.98 & 0.92 & -1.19 & 11.98 & 0.68 & 17.44 & 3 \\
\hline A0022 & & 15.69 & 2.21 & 24.71 & 0.87 & -1.1 & 1.92 & 0.69 & 15.88 & 4 \\
\hline A0001 & & 11.59 & 1.5 & 22.49 & 1.82 & -1.01 & 1.04 & 0.57 & 11.6 & 5 \\
\hline A0024 & & 12.67 & 1.75 & 23.44 & 0.61 & 2.01 & 1.59 & 0.64 & 10.52 & 3 \\
\hline A0029 & & 15.67 & 2.26 & 24.45 & 0.57 & -1.03 & 1.64 & 0.23 & 15.63 & 3 \\
\hline A0030 & & 15.03 & 2.5 & 24.03 & 0.81 & -1.12 & 1.89 & 0.59 & 15.69 & 3 \\
\hline A0025 & C02 & 12.89 & 1.56 & 23.95 & 0.53 & 2.44 & 1.5 & 0.55 & 11.34 & 3 \\
\hline A0027 & & 11.68 & 1.01 & 22.8 & 0.39 & -1.65 & 0.66 & 0.11 & 11.89 & 2 \\
\hline A0028 & & 10.99 & 0.15 & 22.86 & 0.39 & 13.96 & -3.67 & 0.66 & 10.9 & 2 \\
\hline A0026 & & 10.89 & 0.1 & 22.33 & 0.22 & 13.75 & -3.22 & 0.42 & 10.05 & 2 \\
\hline A0034 & & 9.88 & 0.157 & 20.04 & 0.69 & 13.67 & -4.24 & 0.091 & 10.88 & 1 \\
\hline A0035 & & 6.94 & 0.12 & 3.77 & 0.56 & 17.88 & -4.13 & 0.086 & 0.84 & 1 \\
\hline A0032 & & 4.55 & 0.093 & 2.56 & 0.38 & 22.67 & -3.55 & 0.082 & 0.77 & 1 \\
\hline A0033 & & 6.99 & 0.18 & 3.88 & 0.49 & 19.44 & -3.99 & 0.084 & 0.78 & 1 \\
\hline A0036 & & 3.56 & 0.085 & 0.98 & 0.39 & 21.5 & -2.89 & 0.079 & 0.68 & 1 \\
\hline A0037 & C01 & 2.02 & 0.066 & 0 & 0.32 & 29.78 & -1.2 & 0.072 & 0.43 & 1 \\
\hline A0039 & & 3.01 & 0.081 & 0 & 0.33 & 25.04 & -2.68 & 0.075 & 0.55 & 1 \\
\hline A0040 & & 3.77 & 0.087 & 1.56 & 0.48 & 19.33 & -3.73 & 0.08 & 0.71 & 1 \\
\hline A0041 & & 4.16 & 0.09 & 0 & 0.43 & 22.12 & -3.29 & 0.081 & 0.68 & 1 \\
\hline A0002 & & 2.54 & 0.07 & 0.32 & 0.34 & 30.01 & -1.9 & 0.07 & 0.38 & 1 \\
\hline A0038 & & 1.86 & 0.053 & 0 & 0.29 & 33.68 & -0.95 & 0.063 & 0.29 & 1 \\
\hline
\end{tabular}

\section{Choice of reference profiles and discrimination thresholds}

In order to characterize the classes, we introduce the following reference profiles: (r1 and r2) such that $\mathrm{r} 2$ (best profile) is greater than $\mathrm{r} 1$ (low profile). To calculate these two reference profiles ( $\mathrm{r} 2$ and $\mathrm{r} 1$ ) must apply the following formula Mousseau and Slowinski (1998): 


$$
g_{j}\left(\mathrm{r}_{\mathrm{k}}\right)=\frac{1}{2}\left\{\frac{\sum_{a_{i} \rightarrow C_{\mathrm{k}-1}} g_{j}\left(a_{i}\right)}{n_{\mathrm{k}-1}}+\frac{\sum_{a_{i} \rightarrow C_{\mathrm{k}}} g_{j}\left(a_{i}\right)}{n_{\mathrm{k}}}\right\}
$$

Where $\mathrm{n}_{\mathrm{k}}$ and $\mathrm{n}_{\mathrm{k}-1}$ is the number of shares respectively associated with the categories $\mathrm{C}_{\mathrm{k}}$ and $\mathrm{C}_{\mathrm{k}-1}$. As initial values for the thresholds of indifference and preferences, their values are set arbitrarily relative to Min $\left(\left(\Delta \mathrm{g}_{\mathrm{j}}\right)\right.$ as follows:

$$
\left\{\begin{array}{l}
q_{j}\left(r_{i}\right)=0.05 g_{j}\left(r_{i}\right) \\
p_{j}\left(r_{i}\right)=0.1 g_{j}\left(r_{i}\right)
\end{array}\right.
$$

\begin{tabular}{|c|c|c|c|c|c|c|c|c|c|}
\hline \multicolumn{10}{|c|}{ Table 7: Pessimistic profile (r2) and discrimination thresholds } \\
\hline & g1 & g2 & g3 & g4 & g5 & g6 & g7 & g8 & g9 \\
\hline$r_{2}$ & 18.72 & 7.88 & 26.13 & 1.22 & 0.97 & 6.63 & 0.84 & 17.18 & 3.38 \\
\hline q & 0.94 & 0.39 & 1.31 & 0.06 & 0.05 & 0.33 & 0.04 & 0.86 & 0.17 \\
\hline $\mathrm{p}$ & 1.87 & 0.79 & 2.61 & 0.12 & 0.1 & 0.66 & 0.08 & 1.72 & 0.34 \\
\hline
\end{tabular}

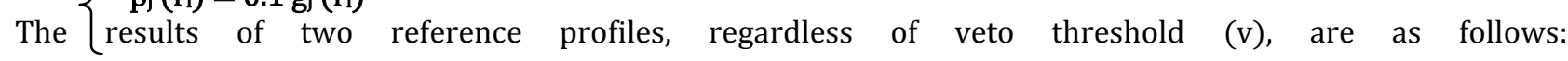

\begin{tabular}{lrrrrrrrrr}
\hline \multicolumn{10}{c}{ Table 8: Optimist profile (r1) and discrimination thresholds } \\
\hline & $\mathrm{g} 1$ & $\mathrm{~g} 2$ & $\mathrm{~g} 3$ & $\mathrm{~g} 4$ & $\mathrm{~g} 5$ & $\mathrm{~g} 6$ & $\mathrm{~g} 7$ & $\mathrm{~g} 8$ & $\mathrm{~g}$ \\
\hline $\mathrm{r} 1$ & 8.15 & 0.65 & 12.12 & 0.53 & 14.35 & 1.57 & 0.25 & 6.33 & 1.83 \\
$\mathrm{q}$ & 0.41 & 0.03 & 0.61 & 0.03 & 0.72 & 0.08 & 0.01 & 0.32 & 0.09 \\
$\mathrm{p}$ & 0.81 & 0.06 & 1.21 & 0.05 & 1.43 & 0.16 & 0.02 & 0.63 & 0.18 \\
\hline
\end{tabular}

Following the two reference profiles $\mathrm{r} 2$ and $\mathrm{r} 1$, a company can be classified:

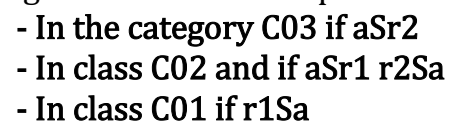

\subsection{Exploitation of upgrade relation and presentation of the results}

\begin{tabular}{|c|c|c|}
\hline \multicolumn{3}{|c|}{ Table 9: Final Classification of companies by procedures } \\
\hline Actions (Companies) & Pessimistic procedure & Optimistic procedure \\
\hline A0021 & C03 : healthy & C03 : healthy \\
\hline A0006 & C03 : healthy & C03 : healthy \\
\hline A0009 & C03 : healthy & C03 : healthy \\
\hline A0007 & C03 : healthy & C03 : healthy \\
\hline A0008 & C03 : healthy & C03 : healthy \\
\hline A0019 & C03 : healthy & C03 : healthy \\
\hline A0003 & C03 : healthy & C03 : healthy \\
\hline A0005 & C03 : healthy & C03 : healthy \\
\hline A0012 & C03 : healthy & C03 : healthy \\
\hline A0013 & C03 : healthy & C03 : healthy \\
\hline A0004 & C03 : healthy & C03 : healthy \\
\hline A0010 & C03 : healthy & C03 : healthy \\
\hline A0011 & C03 : healthy & C03 : healthy \\
\hline A0014 & C03 : healthy & C03 : healthy \\
\hline A0015 & C03 : healthy & C03 : healthy \\
\hline A0016 & C03 : healthy & C03 : healthy \\
\hline A0018 & C03 : healthy & C03 : healthy \\
\hline A0023 & C02 : Risky & C03 : healthy \\
\hline A0017 & C03 : healthy & C03 : healthy \\
\hline A0020 & C03 : healthy & C03 : healthy \\
\hline A0031 & C02 : Risky & C02 : Risky \\
\hline A0022 & C02 : Risky & C02 : Risky \\
\hline A0001 & C02 : Risky & C02 : Risky \\
\hline A0024 & C02 : Risky & C02 : Risky \\
\hline A0029 & C02 : Risky & C02 : Risky \\
\hline
\end{tabular}

The results of the classification of companies in three categories predefined for the pessimistic and optimistic procedures are respectively presented in the following table: 


\begin{tabular}{|c|c|c|}
\hline A0030 & C02 : Risky & C02 : Risky \\
\hline A0025 & C02 : Risky & C02 : Risky \\
\hline A0027 & C01 : failing & C02 : Risky \\
\hline A0028 & C01 : failing & C02 : Risky \\
\hline A0026 & C01 : failing & C02 : Risky \\
\hline A0034 & C01 : failing & C02 : Risky \\
\hline A0035 & C01 : failing & C01 : failing \\
\hline A0032 & C01 : failing & C01 : failing \\
\hline A0033 & C01 : failing & C01 : failing \\
\hline A0036 & C01 : failing & C01 : failing \\
\hline A0037 & C01 : failing & C01 : failing \\
\hline A0039 & C01 : failing & C01 : failing \\
\hline A0040 & C01 : failing & C01 : failing \\
\hline A0041 & C01 : failing & C01 : failing \\
\hline A0002 & C01 : failing & C01 : failing \\
\hline A0038 & C01 : failing & C01 : failing \\
\hline
\end{tabular}

Source: made by us

Based on these results, we can see Electra TRI provides good classification percentages are of the order of 95.12 $\%$ and $82.93 \%$ for the optimistic and pessimistic procedures respectively.

An analysis of errors in classification showed that only in the case of pessimistic procedure there are four serious errors such C02: C01 (A0027, A0028, A0026 and A0034) and three errors Type C03: C02 (A0023, A0031 and A0022) that is to say, the BTS adopt a pessimistic procedure will consider companies A0027, A0028, A0026 and A0034, as faulty as they are risky and the A0023, A0031 and A0022 companies as risky then they are healthy.

These companies will be automatically deprived of credit. In general, the classification errors produced by the pessimistic procedure are due to an underestimation of the performance of companies (firms are assigned to a lower category relative to their initial category: 7 errors are of this type, while the optimistic procedure gave only two misclassifications type C03: C02. Recall that the pessimistic procedure is applied to decision problems in which a policy of "caution" is needed in lending by banks to less efficient firms. But the tightening of credit conditions increases the failure rate. This result confirms the general idea that the optimistic procedure must be adopted by most banks to reduce the risk of business failure as the risk of this procedure is minimal.

Finally, the results above confirm that the ELECTRE TRI method is an operational and effective tool in assessing the risk of failure.

\subsection{Sensitivity analysis of results}

In ELECTRE TRI allocation depends on the value of the cutting level $(0.5 \leq \lambda \leq 1),(\lambda=0.75$ default software $)$ and assignment retention procedure. It is important to check whether the results are sufficiently stable because the evolution of the assignment based on the $\lambda$ value provides interesting information to accurately estimate the characteristics of an action and the strength of its assignment. And the analysis of sensitivity to different thresholds cutting gives results that assess the importance of changes that have occurred for an assignment to another. We retain the following thresholds cut: $\lambda=0.6, \lambda=0.7$ and $\lambda=0.8$; applying ELECTRE TRI we note that the results of the sensitivity analysis with respect to the variation of cutting thresholds remain stable with a slight deviation from where the robustness of the methodology.

\subsection{Conclusion}

Bank financing is still the heaviest stress on small and medium enterprises. The problem of access to loans faced by the Tunisian SMEs has a significant negative impact not only on the growth and survival of these enterprises, but a real threat to the successful opening of the Tunisian economy internationally.

The methodological interest of this paper is to find a method which adapts itself best to the problem of the process evaluation of the default risk. In our case, it is the application of two multicriteria decision-making approaches namely: the ELECTRE III method and the ELECTRE TRI method. It should be noted that the multicriteria decision-making methods, seem to have a sponsor in this type of problems and in general in financial classification problems.

The results obtained by these two methods, have shown that the application of a policy of prudence, a pessimistic procedure in the granting of loans by the Tunisian Solidarity Bank of Mahdia, as one of the financial 
support structures relative to investment credits, is the main obstacle to the creation, development and sustainability of Tunisian SMEs as tight credit conditions increases the failure rate, an optimistic procedure is therefore recommended.

\section{References}

Adair (P.) et Fhima (F.). (2009), Accès au crédit et promotion des PME en Tunisie. 5th International Conference on Finance, March 11-13, Hammamet, Tunisie, Euro-Mediterranean Economics and Finance Review 2009, Vol. 4, 3, Third Quarter, pp. 26-52.

Altman E. I. (1983), Corporate Financial Distress, A complete Guids to predicting, avoiding and dealing with Bankruptcy. John Wiley, New York 1983.

Altman E.I., Marco G. et Varetto F. (1994), Corporate distress dignosis: Comparisons using linear discriminant analysis and neural networks (The Italien experience). Journal of banking and finance (1994), vol.18, p.505-529. http://dx.doi.org/10.1016/0378-4266(94)90007-8

Ang J.S (1992), On the theory of finance for private held firms. The Journal of Small Business Finance, vol. 1, p. 185-203.

Ang J.S. (1991), Small business uniqueness and the theory of financial management. The Journal of Small Business Finance, vol.1, p. 1-13.

Armour, J. et Cumming, D. (2005), Bankruptcy Law and Entrepreneurship. American Law and Economics Review Forthcoming.

Audretsch D.B. (2002), The Dynamic Role of Small Firms: Evidence from the U.S., Small Business Economics, 18(1-3), pp. 13-40. http://dx.doi.org/10.1023/A:1015105222884

Berger A. et Udell G. (1998), The economics of small business finance: the roles of private equity and debt markets in the financial growth cycle. Journal of Banking and Finance, vol. 22, p. 613-673. http://dx.doi.org/10.1016/S0378-4266(98)00038-7

Berger, A.N., Rosen, R.J., Udell, G.F, (2007), Does market size structure affect competition? The case of small business lending. Journal of Banking and Finance 31, p.11-33. http://dx.doi.org/10.1016/j.jbankfin.2005.10.010

Belz L. et Gauthier O. (2000), Innovation et croissance économique : rôle et enjeux du financement des PME. Revue Internationale PME 2000, 13(1), pp. 1-16. http://dx.doi.org/10.7202/1008670ar

Bouyssou D et Roy B, (1987), La notion de seuils de discrimination en analyse multicritère, INFOR, Vol. 25,4, 302-313.

Cole R., Goldberg L. et White L. (2004), Cookie-cutter versus character: the micro structure of small business lending by large and small banks. Journal of Financial and Quantitative Analysis, vol.39, p. 227-252. http://dx.doi.org/10.1017/S0022109000003057

Collongues Y. (1977), Ratios financiers et prévision des faillites des petites et moyennes entreprises. Revue banque (1977), n³65, p.963-970.

Conan. J et Holder. M. (1979), Variables explicatives des performances et contrôle de gestion dans les PME. Thèse d'Etat, université de Paris-Dauphine, 1979.

Crucifix. F et Derni. A. (1993), Symptômes de défaillance et stratégie de redressement de l'entreprise. Aux Edition Maxima. Paris, 1993, p18-21.

Daily C.M., Dalton D.R. et Cannella A.A., (2003), Corporate Governance: Decades of Dialogue and Data. Academy of Management Review, vol. 28, n³, p. 371-382. http://dx.doi.org/10.2307/30040727

Ebaid, I.E.S. (2009), "The impact of capital-structure choice on firm performance: empirical evidence from Egypt", The Journal of Risk Finance, Vol. 10 No. 5, pp. 477-487. http://dx.doi.org/10.1108/15265940911001385

Edwards T., Delbridge R. and Munday M. (2005), Understanding innovation in small and medium-sized enterprises: a process manifest, Technovation. 25(10), pp. 1119-1127, 2005. http://dx.doi.org/10.1016/j.technovation.2004.04.005

Gallina A. (2002), SMEs Contribution to the Creation of the Euro-Mediterranean Region, ERF Working Papers Series, Working Paper 0106.

Hallberg K. (2000), A Market-Oriented Strategy for Small and Medium-Scale Enterprises, IFC Discussion Paper 48.

Jensen M. (1986), Agency Costs of Free Cash Flow, Corporate Finance and Takeovers. American Economic Review, vol. 76, n², p. 323-329.

Jensen M. et Meckling W. (1976), Theory of the Firm: Managerial Behavior, Agency Costs, and Ownership Structure. Journal of Financial Economics, vol. 3, p. 78-133. http://dx.doi.org/10.1016/0304405X(76)90026-X

Koenig. G. (1985), Entreprises en difficultés: des symptômes aux remèdes. Revue Française de Gestion, JanvierFevrier 1985. 
Lawless, R. et Warren, E. (2005), Myth of the Disappearing Business Bankruptcy. California Law Review $93: 743$.

Lee, S., Yamakawa, Y. \& Peng, M. (2007), Entrepreneurship and the Barrier to Exit: How Does an EntrepreneurFriendly Bankruptcy Law Affect Entrepreneurship Development at a Societal Level?. Working paper (2007).

Leland, H. et Pyle D. (1977), Informational Asymmetries, Financial Structure, and Financial Intermediation. The Journal of Finance 32, p. 371-387. 1977. http://dx.doi.org/10.2307/2326770

Letza, S., Kirkbride, J., Sun, X., Smallman, C., (2008),"Corporate governance theorising

Mousseau V. et Slowinski R. (1998), Inferring an ELECTRE TRI Model from Assignment Examples », Journal of Global Optimization, 12, p.157-174. http://dx.doi.org/10.1023/A:1008210427517

Myers S. et Majluf N. (1984), Corporate financing and investment decisions when firms have information that investor do not have. Journal of Financial Economics, vol. 13, p. 187-221. http://dx.doi.org/10.1016/0304405X(84)90023-0

Nahmias .L. (2005), Impact économique des défaillances d'entreprise. BULLETIN DE LA BANQUE DE FRANCE $\mathrm{N}^{\circ} 137$ - MAI 2005.

Roy B. (1988), Des critères multiples en recherche opérationnelle : pourquoi ?, in Rand G.K. (éd), Operational Research 87, Elsevier Science Publishers B.V. (North-Holland), p. 829-842.

Roy B. (1985), Méthodologie multicritères d'aide à la decision, Paris, Ed. Economica, 1985.

Roy B. (1978), Un algorithme de classement fondé sur une représentation floue des préférences en présence de critères multiples, Cashier du centre d'Etudes de Recherche Opérationnelle, Vol. 20, 3-24.

Sadeghian, N.S., Latifi, M.M., Soroush, S. and Aghabagher, Z.T. (2012), "Debt policy and corporate performance: empirical evidence from Tehran Stock Exchange companies", International Journal of Economics and Finance, Vol. 4 No. 11, pp. 217. http://dx.doi.org/10.5539/ijef.v4n11p217

Sharabany R. (2004), Business failures and macroeconomic risk factors. Discussion Papier N²004.06, Bank of Israel, Research Department (2004).

Smith, Clifford W. et Jerold B. Warner. (1979), On financial contracting: An analysis of bond covenants. Journal of Financial Economics, June: pp 117-61. http://dx.doi.org/10.1016/0304-405X(79)90011-4

Varun Dawar, (2014),"Agency theory, capital structure and firm performance: some Indian evidence", Managerial Finance, Vol. 40 Iss 12 pp. 1190 - 1206

Vincke P. (1989), L'aide multicritère à la décision. Bruxelles: Université libre de Bruxelles ; Paris (1989).

Ye (George) Jia. (2009), The Impact of Personal Bankruptcy Law on Entrepreneurship. University of Western Ontario. October 21, 2009

Yu W. (1992), ELECTRE TRI : Aspects méthodologiques et manuel d'utilisation », Document de Lamsade $\mathrm{n}^{\circ} 74$, Université de Paris-dauphine, 1992.

\section{Appendix}

\section{Downward Distillation}

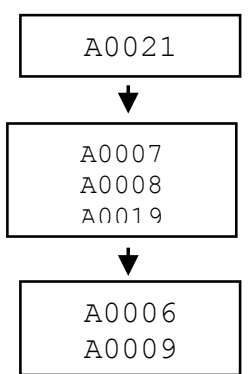

\section{Ranks in the Final Preordre}

\begin{tabular}{|l|l|}
\hline Rank & Action \\
\hline 1 & A0021 \\
\hline 2 & A0006 \\
& A0009 \\
\hline 3 & A0007 \\
& A0008 \\
& A0019 \\
\hline 4 & A0003 \\
& A0005 \\
& A0012 \\
& A0013 \\
\hline 5 & A0004 \\
& A0010 \\
& A0011 \\
& A0014 \\
& A0015 \\
& A0016 \\
\hline 6 & A0018 \\
\hline 7 & A0023 \\
\hline 8 & A0017 \\
\hline 9 & A0020 \\
\hline 10 & A0031 \\
\hline 11 & A0022 \\
\hline & A0001 \\
\hline
\end{tabular}




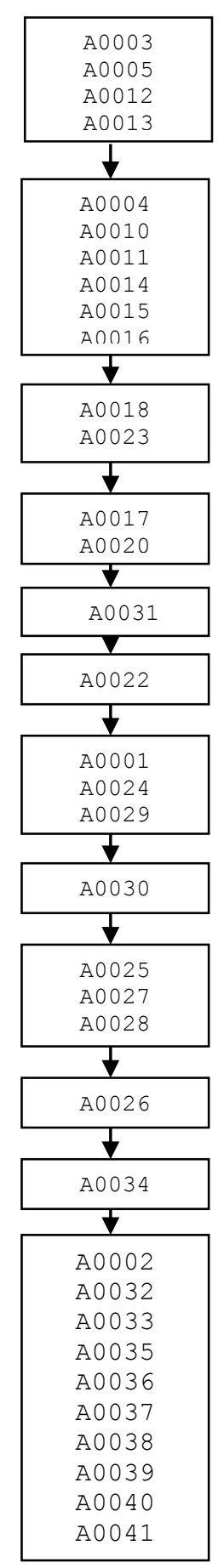

\begin{tabular}{|l|l|}
\hline & A0029 \\
& A0030 \\
\hline 12 & A0025 \\
\hline 13 & A0027 \\
& A0028 \\
\hline 14 & A0026 \\
\hline 15 & A0034 \\
\hline 16 & A0035 \\
\hline 17 & A0032 \\
& A0033 \\
& A0036 \\
& A0037 \\
& A0039 \\
& A0040 \\
\hline 18 & A0002 \\
& A0038 \\
\hline
\end{tabular}

